\title{
THE SAGA OF THE VOITKA BROTHERS IN THE ESTONIAN PRESS: THE RISE AND FALL OF A HEROIC LEGEND
}

\section{Eda Kalmre}

\begin{abstract}
Ülo and Aivar Voitka, who had been found guilty in petty offenses during the Soviet period, hid from the authorities in the woods for 14 years, conducting robberies also during this period. The capture and the following arrest of the Voitka brothers was a media event which attracted the attention of both the entertainment and commercial circles. The Voitka case prompted a public dialogue about social and political values in the Estonian society. The article analyses how heroic legend repertoire has influenced the media case of the Voitkas, its literary associations and the historical Estonian forest brother lore*.

Keywords: hero, media legend, journalism, Estonian history, literature, society.
\end{abstract}

\section{Introduction}

Ülo (born 7.10.1968) and Aivar Voitka (born 17.03.1967) grew up in a family of seven children in a country household in southern Estonia. Ülo graduated from the primary school and continued his studies in a school of agriculture, but both brothers, especially Aivar, had problems with learning and had records of petty offense since boyhood. The boys also liked to roam around in the forests on their own and sometimes lived there for days and nights, skipping school. In 1986 they fled into the woods after having stolen a tractor with a shelter for construction workers. An accessory to the theft was Aavo, Aivar's and Ülo's older brother, who took the blame and was convicted by the Soviet court and sentenced to prison for seven (!) years.

Ülo and Aivar reached the age of military service and should have joined the Russian Army for their compulsory term. For this theft and for evading military service, the Russian militia (police) declared them to be dangerous recidivists wanted all over the Soviet Union.

The Voitka brothers lived in forests for years, often changing their locations and dwelling mainly in underground bunkers. In 
1991 the political system changed, the Soviet Union collapsed and Estonia regained its status as an independent and democratic state. But the brothers stayed in the woods.

While living in the forest, the Voitka brothers had several encounters with the police and forest officials, and always mastered the situation. The brothers became objects of public awareness in June 1999 when they forced two policemen to give away their official weapons, mobile phones and car keys. Since this episode the seizure of the brothers became a matter of honour with the police, and something like a Voitka cult began to spread in Estonia. Every week papers wrote about their life and the police search for them.

Regardless of the fact that they were searched by all police forces in Estonia, the brothers remained in flight for almost another ten months. On July 2 Helju Voitka, their mother, pleaded Aivar and Ülo to come out of the woods. On August 25 the brothers sent a public letter to two major dailies containing a plea to the government of Estonia, where they asked for immunity and a permission to come out. The papers published their letter, which swarmed with spelling mistakes and had been signed - along with their names - as 'Voitkas, the forest brothers'. The government did not comment on the letter as its authenticity was questionable and it was not sent to the government through routine channels.

The Estonian police finally managed to apprehend the brothers on February 29, 2000. All Estonians could follow the course of events on a live report broadcast over the public state-regulated TV channel, and it was a front-page story in all the major dailies. "Like a song festival. Only mulled wine was missing." A telling headline in the major Estonian weekly Eesti Ekspress (02.2000) read "The seizure of the Voitka brothers was the media highlight of this winter".

During the years that the brothers had been hiding in the woods, they had committed dozens of smaller and larger acts of theft, mainly robbing food, clothes and money they needed for living. They had taken weapons from three policemen. Robbing weapons of office was perhaps the most serious of the offenses they 
committed, but the list included also kidnapping and unlawful detainment of a man and a woman for one and a half days, and firing towards policemen in the course of arrest. The Voitkas had remained in the forests for 14 years.

In retrospect, there has been no comparable event in the newly independent Estonia to attract the interest of so many people and to be exploited for the purposes of both entertainment and commercialization. This is an utterly remarkable and atypical story in the modern society. The roots of its telling and understanding lie in both the period of the historical legend of forest brothers and the sociopolitical situation a few years before. A narrative researcher cannot help noticing the impact of folk narratives on the media legend concerning the Voitka brothers. The following observations discuss the aspects of the media legend ranging from its structure to the social contents and the overlapping of its contents with the heroic legend. A folklorist used to distinguish between folk tale types and motifs can easily recognise a folkloric character, though juxtaposing a modern media hero and a folkloric hero is much more intriguing and more complicating.

\section{The tale of the Voitka brothers as a media discourse}

In a media-driven world there is usually no clear-cut distinction between an actual event and its presentation in the media. In other words, media creates the event, it enables to present the event in the way it finds appropriate. Media narration about the Voitka brothers combines many different angles and subplots, comments and versions. Simultaneously with the articles discussing the course of events of the Voitka case, articles analysing the journalistic heroic saga were published. This is, in a way, a genre of cognitive discourse where historians and literary theorists, psychologists and sociologists functioned as consultants, advisors and experts. The Voitka saga entailed a number of smaller and major discussions about history, society and politics. In March 2000, as a folklorist studying the field, I was asked to give an interview about the legends of Estonian outlaws, their social and political background in history. In the written press, however, the opinions of journalists prevailed. Nevertheless, hun- 

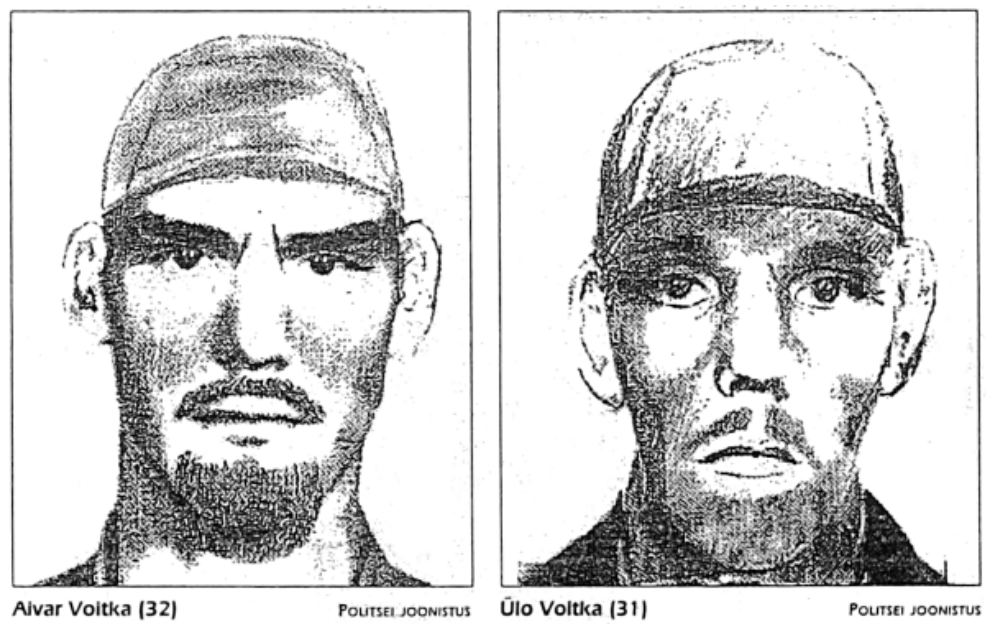

Figure 1. "The Voitka brothers enjoy the support of the locals". Postimees, 06. 14.1999.

dreds of people expressed their views in Internet portals and forums. These texts, functioning as archived research material, are an important source for public attitudes and opinions on the Voitka case and its reverberations in the media.

The Voitka saga evolved through three successive stages: (i) the period prior to their capture, (ii) the period following their arrest, and (iii) the period following the trial. Each of these three stages display certain characteristic features. The first stage could be characterised by a folklorisation process. The mysterious image of forest brothers was intensified by police sketches published in various papers (Figure 1.) Certainly, the media told the Voitka tale according to the principles of heroic outlaw legends (see Holt 1984; Gašparíková, Putilov 2002). The evasiveness of the brothers transformed them into skilful and magical heroes in the public mind. The first stage of the events intended to provide the readers with excitement, adventure and entertainment. The general public could follow the story of the Voitka brothers' going to the woods, hunt for them, their outwitting the Soviet and Estonian police and other authorities. The Voitka case was discussed by the most reputed journalists. In the leading Estonian daily newspaper "Postimees", for example, most articles about the Voitka brothers were written by Toomas Sildam, who, 
relying on his sources, offered four intriguing versions of the arrest of the Voitka brothers in his news article "The Voitka brothers enjoy the support of the locals" (June 14, 1999). The most unlikely (in other words, boring!) version was the brothers' surrender without a fight.

\section{His/(s)tory and folk/lore}

Oskar Loorits, the reputed Estonian folklorist of the older generation, argues in his essay (1933) about the difference between these two terms. According to him the difference lies in that a "story" is a fact, the way it actually happened, whereas "lore" is how the "story" is wished to be seen. Analogously to a well-known Estonian film's (Viimne reliikvia, or 'The Last Relic', which promoted freedom from oppressors ${ }^{1}$ ) turning into a cult film, the flight of the Voitka brothers formed an associative link to the Estonians' aspirations of freedom in the period of national awakening.

The media attuned to the saga of the Voitka brothers with an article published on January 5, 1995 in Maaleht, a paper for the rural population ${ }^{2}$ (Hagelberg, Oll 1995). The article, which did not receive much public attention, was a story with a nationalromanticist undertone about disobedient boys and their being drawn to the woods, the theft of the tractor and the shelter (they needed a place to stay while having a conflict with relatives). The article was illustrated with photos of their "bunker architecture as an inherent part of the national architecture". All the thefts conducted by the Voitkas and their conflicts with the police were described in a slightly humorous undertone. Five years later, in 2000, the journalists of Maaleht of the time characterise the article accordingly:

Like me, Hagelberg has a university degree in history, and perhaps owing to this fascination with the forest brothers, our article expressed quite romantic notions. If we were to write the article now, it would probably be quite different; nevertheless, I never considered them, nor do now, true criminals. (Lõhmus 2000). 
This journalistic metatext reveals two main aspects of the Voitka story: firstly, the straightforward attempt to link the events with history, and secondly, the issue of justice.

The entire Voitka saga presents, in a sense, an idealised view of the freedom fight of the recent past. People associated the most famous forest brothers of the recent past with legends about the horse thief Jüri Rummo (Rummu Jüri), the Estonian "Robin Hood". One of such forest brothers was Ilp, who was active in the postwar period on the island of Saaremaa. In 2001 I recorded in Sõrve, Saaremaa, two typical plots of the Estonian outlaw legend describing Ilp's courageous pranks, how he, dressed in women's clothes or a military uniform, pulled the leg of Soviet soldiers. Ilp's crimes of blood are less remembered but the heroic myth glorifying his actions is very much alive and feeds on repetitive performances of such typical plots.

While discussing the topic of forest brothers, it is important to remember that a fragile mythological background is characteristic of the political forest brother lore in the entire Baltic area. Only a few decades ago local informants were reluctant to talk to a folklorist interviewing them about August Sabbe, the last Estonian forest brother who had to hide himself for 33 years and tragically died in 1978. For the local people he was almost a mythological character and his death was not believed, as heroes never $\operatorname{die}^{3}$.

The Voitka brothers were presented in the media as heroes who never surrender and whose one reason for hiding in the woods was to escape the Soviet military service. A hero, however, ought to be a collective image of what was felt by thousands of people of the time, and the hero should be doing things that many would like to but nobody dares. In the media discourse the argumentation of the Voitka-experts contained opposing views on whether evading the (Soviet) military service was a feat of heroism or a recreant act. According to psychologist Inge Tael (2000) it was a feat of heroism. Literary theorist Rein Veidemann, however, expressed the opinion that the boys escaped in the woods out of cowardliness rather than displayed courage like their fathers and grandfathers. 
What happened to them is by no means comparable to what happened to the Jüri Rummos, Robin Hoods, or Robinsons. The frequently applied comparison with forest brothers is inappropriate, if not disparaging of the forest brothers' movement of the 1940s-1960s (Veidemann 2001).

I tend to agree with Rein Veidemann, because not only was Enn of Erastu a definitely negative character in the Estonian literature $^{4}$, the attitudes towards evaders have been disapproving even in folklore. This applies even to the evaders from the Soviet military service, as evasion from any responsibility and obligation has never been considered an act of courage. Oral narrative repertoire includes stories about evading military service and the topic has also been of interest to journalism today (see Illak 2004). We can quite confidently agree that the issue has been topical for centuries and ways how to evade the Russian army have been discussed in the written press since the very beginning. The earliest report on the topic is probably an article by Otto Wilhelm Masing in the paper Marahva Näddala-Leht, discussing a court ruling at a case where five young country men had feared doing the military service and had all their teeth pulled out to be found unfit for military service. This case had an unfortunate ending as their deception became known: they still had to join the army and, on top of that, were sentenced ten pairs of lashing (Masing 1823: 215).

In folklore poetic legend justice usually prevails: evaders escape the service but receive some other punishment. Several articles published in the Estonian press around the peak of the Voitka affair $^{5}$ bear similitude with one of the most remarkable jokes in the repertoire of the Soviet period.

A country boy had great fear for the Russian army. Didn't know what to do to escape the military service. His acquaintance gave him an address of a town doctor who might be able to help him for a consideration. The boy even sold his cow to get the required sum together. So he went to town to see the doctor. The doctor accepted his money and gave the boy a checkup. Couldn't find anything wrong with him, the boy was fit as a fiddle. But since he had accepted the money he offered a 
deal: "I could castrate you, and you would be unfit for the service!"

The boy agreed - what of the balls, at least I will be alive! The doctor fixed the boy. After a while the recruitment office did find the boy unfit for service - but not because he lacked genitalia but because he had flatfeet!

Heard in a construction company Harju KEK.

(EFA II 24, 301/2 <Tallinn, Keila - Tiit Birkan (1997))

Together with allusions to history a question was posed whether all forest brothers were indeed heroes and whether recent historical treatments, which generally tend to be critical and condemnatory towards the totalitarian Soviet regime, have not "overexploited" (or glorified) the forest brothers' movement (Koni 2001, Tuvike 2000, etc.)

\section{The Voitka brothers - heroes or criminals?}

This is one of the fundamental questions in narratives about outlaws. The main conflict in these narratives lies in that one party represents the law and the other party stands outside the law. Quite logically, the Voitka brothers were metaphorically compared to folkloric heroes Robin Hood and Jüri Rummo during the whole media saga.

The popular legend about Robin Hood originates in the $14^{\text {th }}-15^{\text {th }}$ century England (see Holt 1984). Over the centuries its literary and popular versions have merged and fed on each other. Progress in television and cinema technology have added to the popularity and stereotyping of Robin Hood, having turned him into an important figure of modern pop culture. Estonian folklore introduces a number of ex lex heroes of the late $19^{\text {th }}$ and early $20^{\text {th }}$ century $^{6}$. Their sphere of action and fame was restricted to a village or parish. The collective image of Estonian outlaws is represented by the character of Jüri Rummo, who stole from the rich and gave to the poor ${ }^{7}$. His wide popularity is based on both folkloric as well as literary sources ${ }^{8}$. The robber and thief, who was active in the Kehtna, Juuru area and the Rapla County, has left an indelible impression in the local lore of the region up to the present day. 
The media image constructed about the Voitka brothers has made it quite difficult to categorise it according to the eight traditional idol types of modern western culture ${ }^{9}$. A historical outlaw does not even occur among the eight types. In fact, a hero and an idol, which requires cultic approach, are not comparable. Regardless of the period the preconditions of an idol creation have always been distance and scope, but in a country the size of Estonia there is not enough either of these (see Loorits 1933: 112; Undusk 2003: 53). The archetype of modern visual and verbal market brand creation is embodiment of a rebellious nature, cultural estrangement and breaking of taboos. The golden examples of such brands are, for example, the drama film Bonnie and Clyde and Harley-Davidson bikes (Mark \& Pearson 2002: 107-121).

The association of historical outlaw types and the Voitka brothers can be done on a very general scale. The hero first and foremost represents the moral values of its time. Characters of folktales were exceptional in some aspects, being otherwise quite simple: eccentrics, master crooks, conquerors, warriors, saints, good or bad (see also Davidson 1984). Now the main criterion for an idol's or hero's fame is no longer extraordinariness but quantity. Certain features that a hero requires, however, continue to be topical. For example, while observing the reconstruction of a sport's hero's image in the Estonian press today, it becomes evident that it requires, next to the special emphasis on gender roles and sexual appeal of our period, also patriotism, fighting spirit, childishness, strong will and strength - in other words, all these features, which have been important for folklore heroes (see Song 2003).

In the discourse about the heroic ideal Mikhail Bakhtin (see Bakhtin 1987, EPL 2001) called the Voitka brothers "a carnival elite", towards whom the public attitude was humorous but entailed a good deal of satire towards themselves and the rest of the world. We are living in the world where legends imitate life, and life imitates legends, and where fictitious movie heroes are imitated by real life heroes, and real life heroes are turned into movie heroes. Estonian author Andrus Kivirähk (2002) argued that the Voitka brothers were merely "home-made gunsmen" compared to, for example, Juri Ustimenko ${ }^{10}$ and his partner in crime, 
who had been reportedly inspired by the famous Russian action films Brat 1 and Brat 2.

Oskar Loorits (1933) has considered the presence of sympathy and antipathy, the two opposing sides, an essential requirement for the emergence of a heroic myth. On the one hand the Voitka brothers were thieves and criminals who robbed stores and left their victims tied up for hours. On the other hand, many people felt sympathy towards them, because they had successfully managed to live in the woods for so long, were very close as brothers, consumed no alcohol, kept their human dignity and handled their problems with as little violence as possible. The prohibition of unnecessary bloodshed has been central in the heroic image in several traditional cultures (see also Gašparíková, and Putilov 2002: 199 ; 163).

The association of the brothers with the woods as if mitigated the seriousness of the crimes they committed. Even today the Estonians like to think of themselves as people fond of nature and forests. This sounds rather paradoxical considering that nearly half Estonia's territory is covered with woods and bogs, but $80 \%$ of the population is settled in towns and settlements. The dream of most Estonians is a small house at the edge of the woods, quite like the home of the Voitkas. Had the brothers been robbing and hiding themselves in town, the general public would have regarded them as commonplace criminals. Readers' response, several Internet comments and views of experts expressed the same opinion (Kolga 2000, Muuli 2001, Soolep 2000).

Preferring positive material over negative in constructing a media hero is characteristic of the written press: everything that does not comply with the positive image is omitted (see Virtapohja 1998). This explains why the media was accused of being impartial: the voice of the victims of the Voitka brothers, or the voice of those who considered the Voitkas criminals, could not be heard. It is characteristic of outlaw legends that violence becomes natural and the victims of outlaws as if deserve their lot. In the original variants of the Robin Hood legend the hero robbed those who lied to him, and the rich usually lied about the amount of the treasures they had taken along. The fact that the victims lied as if gave him moral justification for his criminal behaviour (Holt 
1984: 11). The inveterate horse thief Jüri Rummo transformed in folktales, which fed on literary sources, into the guardian of peasants. Court records, however, do not reveal that Jüri Rummo had inflicted damage only to estate owners and court clerks. On the contrary, his victims were mostly travellers-farmers he met in taverns. However, it appears that he himself and his two accomplices boasted with crimes against the authorities. His unbelievable escapes and the number of crimes certainly inspired rumours, which, with romantic and adventurous exaggerations transformed into legends in people's minds (Ibius 1957).

The victims of outlaws in folktales appear to deserve their punishment, and so are the woman and man held captive by the Voitka brothers considered immoral and undeserving sympathy. The owner of the store they robbed is also suspicious, as he had been known to put aside goods, etc. (Russak 2001). Such transparent reasoning for justification is effective in most outlaw tales. The positive public opinion of the Voitka brothers was furthered also by the use of vocabulary in the newspaper articles. The Voitkas were mostly called lindpriid 'outlaws', metsavennad Voitkad 'Voitkas, the forest brothers', vennad Voitkad 'The Voitka Brothers', and not 'criminals' or 'lawbreakers'.

Legends concerning the punishment of a hero who has committed a crime do, in fact, exist in folklore, though they are considerably less popular than narratives glorifying criminals. For example, in some unquestionably authentic folktales, Jüri Rummo and Stenka Razin are chained indefinitely as a punishment for their crimes (see Oinas 1966).

\section{The Voitkas as a litmus test}

The second stage of the Voitka saga, leading to the culmination of the story which started after the Voitkas were caught, marked the collapse of illusions about their heroism. The turning point was the first television interview with the brothers. Their appearances on television and interviews revealed that the brothers were men of less than average intellect, suffering under the blows of life. (Figure 2.) 


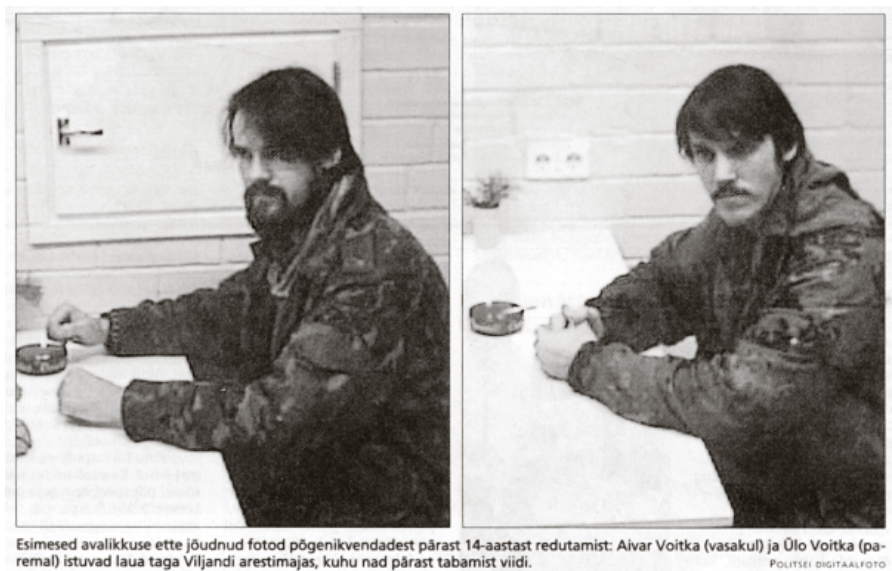

Figure 2. "Aivar and Ülo Voitka wish to be released until hearing". Postimees, 03. 02. 2000.

Here it would be appropriate to once again quote the essay by Oskar Loorits:

...wishfully created fantasy images lose their glow of the supernatural and, through that, their attraction and interest, as soon as, quite unexpectedly, an ordinary person in an ordinary real life situation is encountered. (Loorits 1933: 112).

During the second stage of the Voitka case following their capture, the socio-political aspect of the case was clearly revealed. The heroes are dead - long live the heroes! Or, in other words, people need their heroes especially when they have strong doubts about the social and political values of the society. This period also marked the acme of readers' response mail and Internet comments, concluding with announcing the court's decision. The central topic in many readers' responses and Internet comments was the issues of justice, humanity, punishment and pardoning in the society. Letters sent by Aime Maripuu and Olav Sööt apparently express the views of most people at the time, claiming that the Voitka case was highly unique and should be assessed according to the principles of humanity. The brothers were not heroes but victims of circumstances. The brothers should have been brought out of the woods with the help of a psychologist 
instead of the special police unit. If the president of Estonia could pardon the person whose obstinacy caused the death of 14 soldiers in the tragedy of Kurkse, then pardon should be extended also to the Voitka brothers (see Maripuu 2000, Sööt 2000). The discussions unveiled the reasons behind the public attitude towards the Voitkas and why they were forgiven their criminal past and also explained why the interest of the media and people rose four years after the publication of the first article.

Namely, in the year 2000 several scandals connected with government institutions and officials broke loose or had recently been topical. Skimming through the papers of the period or reading Internet comments leaves the impression of public discontent with the poor police system based mainly on the policemen of the Soviet period, the ten-million-dollar affair of the then president of the Bank of Estonia and its hushing up in the court. The purchase of expensive cars and furniture by members of government (which was, of course, brought to the public notice by the media) caused general indignation. In the Internet comments the situation was repeatedly described with an Estonian proverb Suured sulid sõidavad tôllas, väikesed ripuvad võllas, or 'Big crooks ride in coaches, small crooks hang on the gallows'. The policemen who had given their official weapons to the two starving brothers only intensified the poor image of the police and influenced the public to take the Voitkas' side.

An online poll conducted by the Estonian daily Postimees on March 2 , 2000, asking whether the Voitkas were criminals or not, received 1,705 replies. $65 \%$ of respondents did not consider the Voitka brothers criminals. Therefore the Voitka saga may even be considered a manifestation of social protest, because compared to other crimes conducted in the society, theirs was insignificant.

Without attempting to minimise the guilt of Ülo and Aivar Voitka for hiding in the woods for 14 years, I think they deserve a milder punishment. They spent many years in the woods the period of the Soviet regime, for which they would have probably been deported to Siberia for a long time, had they been captured. Among all the forest brothers who came to be called heroes in the time of independence, there have been 
bandits and murderers. I myself have spent seven months in the woods, including a very harsh winter. We almost turned savage during that time. I am truly amazed to see that the brothers have not turned into wolf-men during these 14 years, that they have not committed any crimes of blood and the material damage they have done is most likely limited to the theft of an expensive car. Nearly 2,000 cars are stolen each year. It would be interesting to know, what a high official of the legislative agency would look like had he been living like the Voitka brothers. (Tuvike 2000).

\section{The display of empathy continues}

Following the capture of the Voitka brothers on February 29, the code of press articles about the Voitkas changed, centring on the sc. 'Mowgli' theme, or how the Voitkas accustomed to their new life in a human society. Newspapers and television mediated how the Voitkas managed with their daily activities: how they listened to the radio, read a book, wrote, had their teeth fixed, got acquainted with the computer, attended the church for the first time, found women friends. Through this theme, which proved more accessible for the general public, the case entered the international media.

The story of the Voitkas is doubly successful because of the role of the robber who outwits policemen and also because of the Mowgli theme. The Voitkas who were used to living in the woods are for people living in comfortable apartments with central heating as strange as someone who has been raised by monkeys in some faraway jungle in Asia or Africa. This "Mowgli effect" successfully sold the Voitka story in the international press, because with a story like this, it does not matter whether the events took place in Siberia, India or Estonia. (Rumm 2000).

True, taming a savage appears more universally comprehensible than the myth of forest brothers associated with national ideology and politics. People of the world have known such folklorised heroes, who after the end of the war continue to behave as if the war is still going on. I happened to come across in a section "Folklore News" in a 1957 issue of an American folklore journal a news 
piece entitled Straggler $X$, published in Los Angeles Times on February 6, 1957. "Straggler X" was the name used for a Japanese soldier who had been the sole survivor and hid himself in the jungle on the island Guam after the end of the World War II. He was probably unaware of the fact that Japan had been defeated. Living on coconuts and fish and terrorising superstitious locals, he managed to remain in recluse for 11 years. The locals scared their disobedient children with him, he was attributed several crimes, probably many of which he did not commit. The sightings of $\mathrm{X}$ were always talked about as of shows, describing how a naked man, fully grown in beard and wearing nothing but a hat, stole food from the frying pan. Eventually, the man was caught red-handed while trying to steal chicken by two local men. (WF 1957: 212-213).

The official comments in the written press repeatedly cautioned readers not to follow consuetude, as everybody must accept full consequences of their actions. While expressing their opinions in the media, authorities like judges, lawyers and policemen, who should have been impartial in their position and abiding the law, as if split in halves and publicly expressed their sympathy. Suffice it to say that the preface to the story about the Voitka brothers by Estonian author Ülo Russak, was written by Märt Rask, the then Minister of Legal Affairs of the Republic of Estonia. Media constantly produced news about the special attention and treatment bestowed on the brothers.

During the year in remand in the houses of detention in Viljandi and Tartu, and in Patarei Prison and in prisons in Pärnu, the younger of the Voitka brothers received special treatment even from the boards of the prisons. In Patarei Prison, where one cell has to accommodate tens of inmates, Voitka was given a cell for two. He shared the cell with a convicted student, who told Ülo, who had been in the woods for 14 years, about the Internet and other innovations in the modern world. (Berendson 2000).

In retrospect we would have to agree with law professor Igor Gräzin who claimed that in the case of the Voitkas the "law of myth" was extended on criminal law (Gräzin 2004). 
It is rather difficult to determine the extent to which the media myth constructed around the Voitka brothers influenced the court's decision. (Randla 2000). Had the Voitkas been found guilty on the initial charge, they would have been sentenced to 15 years in prison, as was sentenced to Jüri Rummo in his time. In reality, Ülo Voitka was sentenced to 2.8 years in prison, 1.3 years of which he physically spent in confinement. (The court found Aivar Voitka non compos mentis.) Constructing a media hero tends to be a process of mutual benefit ${ }^{11}$.For the Voitkas, the benefit lay, no doubt, in influencing the court's decision in their favour. Interviews given by Ülo Voitka and his lawyer served this very purpose, contributing also to his positive image in public.

Legend characters conform to a very simple and clear-cut pattern. Characteristic of this pattern are clear oppositions - there are positive characters and there are negative ones. Analogously to legend characters, media drama arises from a typical fight of adversaries (see Virtapohja 1998). Since the very beginning, antipathy towards those who hunted the Voitkas concluded with an on-the-spot report in the home farm of the Voitkas following the brothers' arrest in the national television by a well-known Estonian television journalist Vahur Kersna. The report enabled the viewers to decide upon which of the characters were negative and which were not. In the written press, former Soviet policeman Mikk Puhalainen was presented as the most negative of the characters - a true Inspector Javert who chases the unfortunate Jean Valjean (Kärmas 1999, etc.).

\section{Other considerations on the iconography of the Voitka saga}

The strength of outlaw legends lies in their social contents and the element of humour (Holt 1984, etc.). The latter enables to explain why such often naïve and superficial stories are passed on from one generation to another and adjust to new cultural contexts. Jüri Rummo, a horse thief clad in women's clothes and knitting a stocking in the carriage, or Ilp, the forest brother, appear similar, likable and humorous at the same time. Pictorialtextual humour played an important role also in the iconography of the Voitka media saga. In an article by Kivirähk (Aasta inimese nääripuu, 'Christmas Party for Person of the Year' 2000) the 
Voitka brothers were depicted as the Ivan the Fools from the woods, who socialised with the Shmigun sisters ${ }^{12}$ at the President's New Year's Party, taking tree-bark and hedgehog meat out of their pockets and eating it. On an April Fool's Day the largescale police operation was mocked in a joke about the Voitka's alleged escape (Voitkad pääsesid põgenema, Sikk 2000). A piece in the weekly Maaleht (Vennad Voitkad suvetuuril, 'The Voitka Brothers on Summer Tour', Vaino 2003) compares the Voitka brothers with other summer entertainers. Caricatures entitled Operatsioon metsavennad, 'Operation Forest Brothers' (Fig. 3) and Karu muidugi ei saanud kõigest jälle päris hästi aru, 'Again, it was the bear who couldn't quite understand what was going on' (Fig. 4) by Urmas Nemvalts in Postimees are both humorous and seriously socio-critical. An advertisement of car tyres emphasising sexuality (see Hiiob 2000) is a rare exception.

Most of the folklore inspired by the Voitka case and the various commercial goods named after the Voitkas convey the message of managing in wilderness and the historical forest brother experience. One of the few examples of authentic Estonian compu-

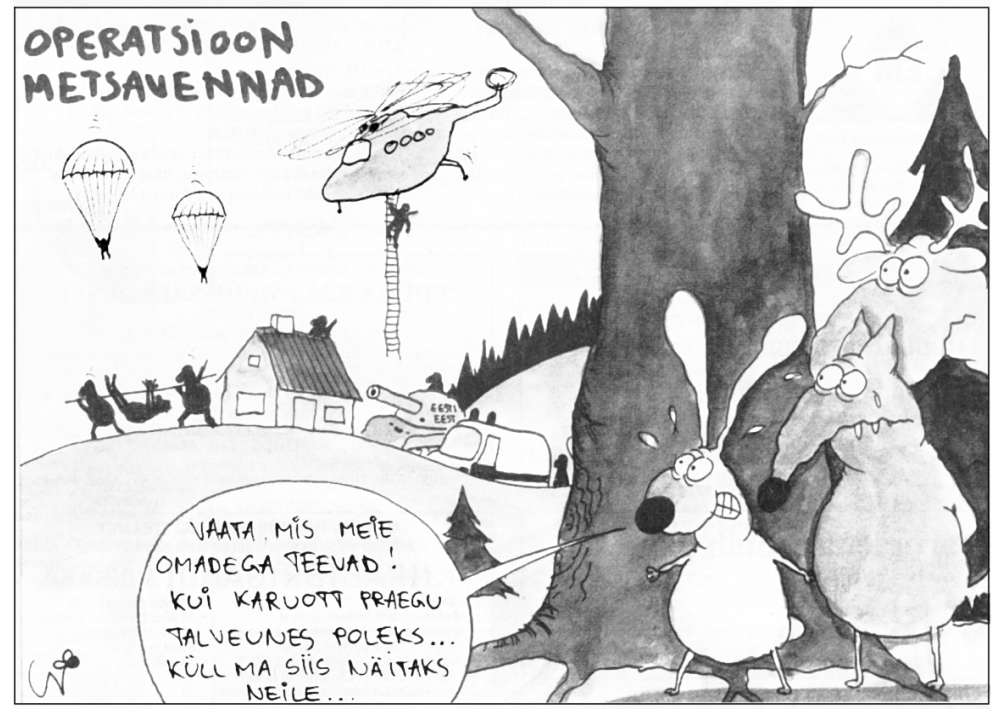

Figure 3: Operation Forest Brothers. Hare: "Look, what they are doing to our men! If the bear wouldn't be hibernating... I would go and kick their butts..." By Urmas Nemvalts, Postimees, 03. 01. 2000. 


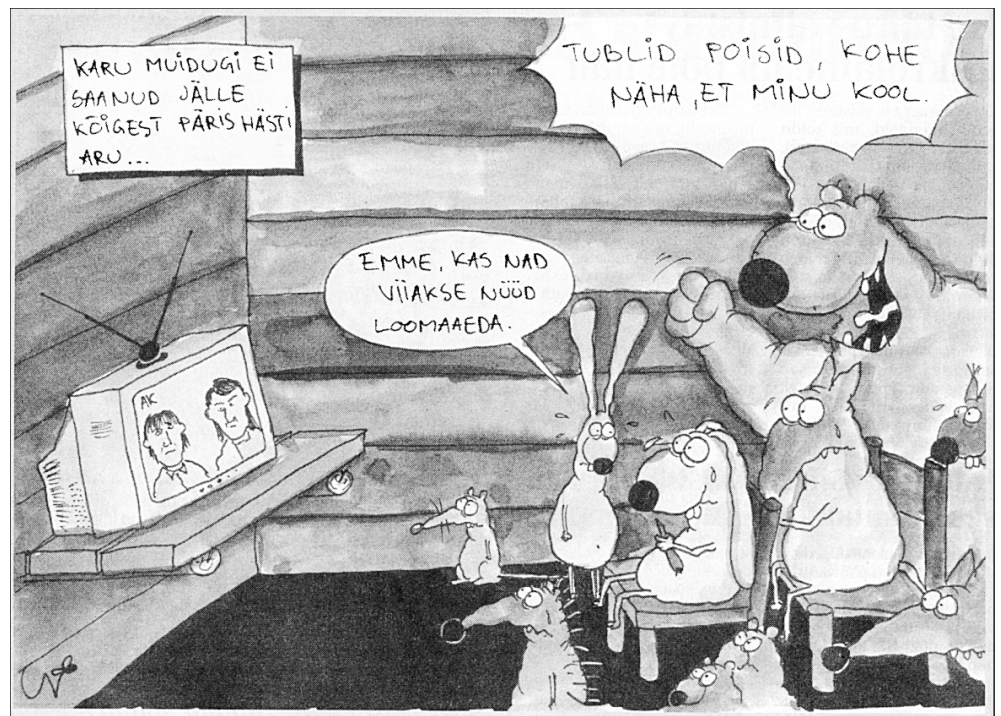

Figure 4: Again, it was the bear who couldn't quite understand what was going on... Hare: "Mommy, are they going to take them to the zoo now?" Bear: "Way to go, boys! My training has finally paid off!" By Urmas Nemvalts, Postimees, 03. 03. 2000.

ter lore is the Curriculum Vitae of Aivar Voitka, which began to circulate in the Estonian Web around the peak of the Voitka media story in March 2000 (Fig. 5). This is a humorous account, which also touches upon several social aspects. Of course, people do not usually read computer lore very closely, and those who forwarded the CV did not seem to be bothered about the fact that Aivar Voitka's resume has a picture of Ülo Voitka, grown in beard and dressed in fatigues, attached to it.

It seems that in contemporary consumer culture the line between reality and reality reconstructed by the media is often quite thin, and often bordering on hyperreality. The Voitkas, heroes produced by the media, fictional characters and mythological characters can nicely co-exist in modern Estonia. Those who might want to disagree could take a look at the official website of Tartu, where a legend to a hiking trail in the vicinity of the town is described as follows: 


\section{Curriculum Vitac}

\section{ISIKUANDMED}

NIMI:
VANUS:
ELUKOHT:
PEREKONNASEIS:
HARIDUS:
KOOLITUS:

Aivar Voitka

32 aastat

Viimased 14 aastat Viljandi metsades Praegune elukoht Viljandi arestimaja

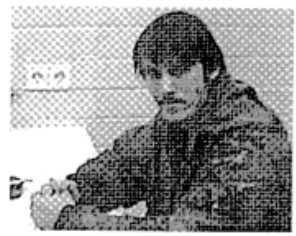

Süütu

Elukool 14 aastat

Praktiline koolitus majaehituses, kokanduses Tăiendkursus: kuuselt-kuusele húppamine

TÖÖKOGEMUS: kalapüuk

puude raiumine

lōkke tegemine

turvateenistus jm. heaks eluks vajalikud kogemused

KEELED:

cesti keel emakeel (vajab praktikat)

valdan kônes ja kirjas lindude ja văhesel mäăral ka loomade keelt

ISELOOMUSTUS: Suhtlen vabalt (14 aastat olen suhelnud Öloga). Oman praktilisi kogemusi meditsiini alalt ( 14 aastat ravinud ennast looduslike vahenditega). Olen entusiastlik ja aktiivne. Olen reisivalmis ( 14 aasta kogemus). Olen peaegu iseseisev (hea kui olcks Ölo tocks). Arvan, et oskan sōita Citroen Xsaraga ja olen muidu lōbus inimene.

Soovin văga osaleda konkursil teie firmas. Olen arenguvõimeline ja leian, et Teie firmas on mul võimalus areneda.

SOOVITAJA:

Ülo Voitka

PALGASOOV: Kott kartulit ja páts leiba.

Figure 5. Letter from Internet:

Curriculum Vitae; Personal information;

Name: Aivar Voitka; Age:32 years; Place of residence/address:In the past 14 years - forests of the Viljandi County.; Current address: Viljandi House of Detention; Marital status: A virgin; Education:The school of life; Training: Practical training in construction, cooking. Further training: jumping from tree to tree; Work experience: fishing, chopping firewood, making fires, security and other experiences necessary for a good life; Languages: Estonian as a mother tongue (requires practice), good command of bird language in speech and writing, average command of animal language; Characterisation: Good communication skills (14 years of experience in communicating with Ülo). I have practical skills in medicine (14 years of experience in treating myself with herbs). I am enthusiastic and energetic. I am willing to travel (14 years of experience). I am almost independent (although it would be nice to have Ülo to rely on). I think that I can drive Citroen Xsara and I am otherwise a nice and happy person. I sincerely wish to take up a position in your company. I am able to progress professionally and I believe that I have very good chances to advance in your company.; Recommendation by: Ülo Voitka; Expected salary: A sack of potatoes and a loaf of bread. 
The trail passes a dugout - the meeting place of free men, among whom there were Tasuja ${ }^{\mathbf{1 3}}$, Chingachgook and the Voitka brothers, the last forest brothers in Estonia, who remained true to their nature long after they needed to. (See also Kohler 2002).

Interestingly, according to another legend offered on the website there is a dwarfs' and ogres' grove nearby! According to contemporary consumer ideology the media saga of the Voitkas connects with a tourist attraction in southern Estonia - it is a forest brother's dugout in the Forest Brother Tourist Farm in SouthEast Estonia, where a tourist can spend a night for a fee, or could attend a theatrical play about the life of forest brothers staged in the summer of 2004. This, in a sense, renders the media saga about the Voitka brothers more understandable.

Visual and verbal aspects are equally important in the media legend about the Voitkas. Photographs intensify the image created by the text. During the first stage of the saga (during the construction of the myth) Estonian newspapers published the police sketches mentioned above, childhood photographs of the Voitka brothers and photos of their dugouts or bunkers. After their capture, the Voitkas appeared before the public as they were expected to - as forest brothers, grown in beard and dressed in camouflage clothing. Ülo Voitka leaves the impression of a neat and orderly young man, appearing in court in his creased trousers and a shirt. Four years after the capture Ülo Voitka appears on a staged photograph, where he leans against a tree in the forest next to his newly bought car with a dreamy expression on his face (February 25, Kroonika, Fig. 6). The photo reminds of his former life as a forest brother and presents Ülo as a man who has advanced in life, and who, according to the article next to the photo, plans to get married.

\section{In conclusion}

The Voitka case was a topical media event during 1999-2000. Presently, the topic of the Voitka brothers has long been dropped by the media. The Voitka tale might be remembered by people who happened to come across the "Voitkad" barbeque lighter fluid in 


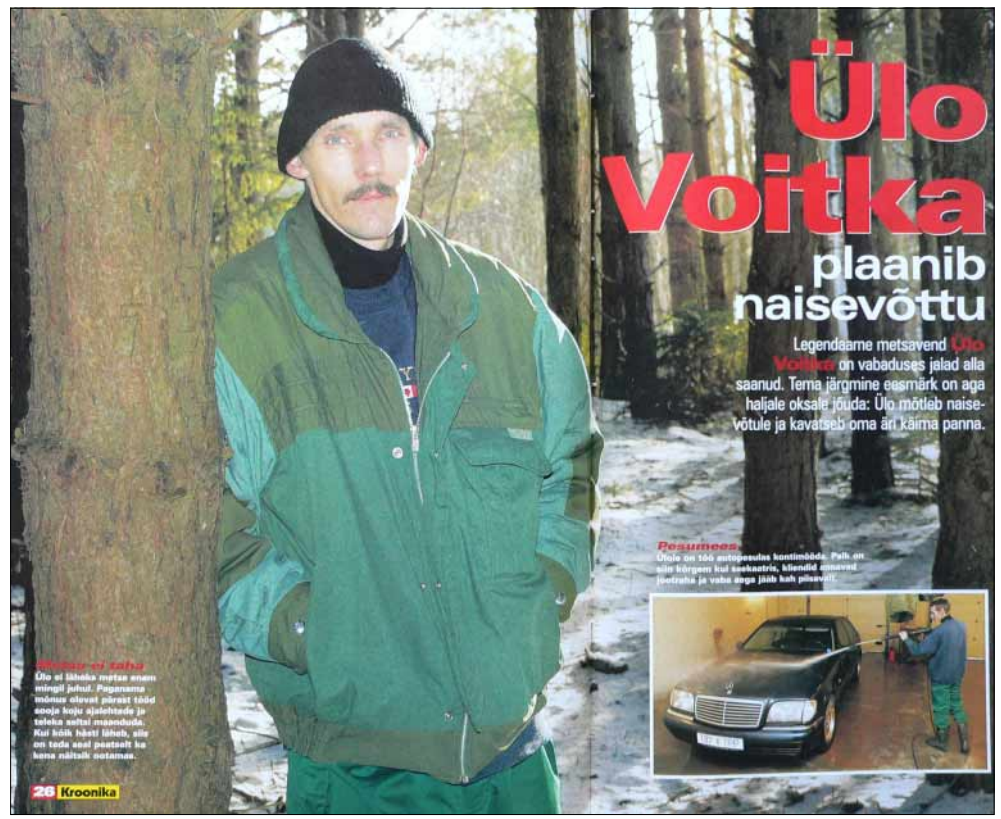

Figure 6. Ülo Voitka plans to marry. Ülo Voitka, the legendary forest brother, has landed on his feet. His next goal will be to have it made: Ülo is thinking about marriage and launching his own business. Kroonika, 25. 02.2004.

the stores in summer 2004, or who played the album Voitkade metsalaulud, 'Forest Songs of the Voitkas' by the Estonian band Jäägermeistrid. In colloquial use and in the Internet the Voitka brothers are metaphors standing for close relations, rebellion, homelessness or reclusion, sometimes simply for someone who is witless. The documentary „V.O.I.T.K.A - Forest Brothers“ directed by Pekka Lehto (Kino Finlandia, Hansa Media 2004) and addressed to the Finnish audience has nothing to add to the thoroughly discussed media story for the Estonian audience, as the film is almost like a parody and appears strange (see Paju 2004, Sildam 2004).

In retrospect, the entire press saga of the Voitka brothers should be valued as a story which evolved in a social interaction between the audience and the media, the narrator. The Voitka case prompted a dialogue about social values. Issues of justice, right- 
eousness, and emotional values, like sympathy, were publicly raised. Attempts to define a modern hero led to shaking the pillars of the forest brother's myth. The Voitka case revealed that in post-modern society law and justice do not operate only in the downwards direction, and not all heroes are at the top. At the moment when we happen to wish for and need heroes, even the least herolike of us may seem as ones. In some aspects the Voitka brothers fitted the stereotype of a legend hero, and for a while they became something of heroes of post-modern nostalgia.

Comments posted in Internet portals and forums point to the fact that the reception of the media legend by the general public was largely conscious. Many people realised that media offered them a legend and consciously enjoyed its entertaining and antigovernmental aspects. (Some examples in the Internet: 'such a nice legend, too bad that it's over'; or a comment about the Voitkas being heroes, paraphrasing a famous fairytale: 'nobody is saying that the Emperor has no clothes, yet everybody knows it'.)

The media saga contained many features characteristic of a heroic legend, which may be interpreted as an attempt to reconstruct a new cultural myth from the old folkloric material.

In sum, the case left the readers the impression that they have already experienced all these things, it was like a déjà vu of a legend, or like a Cinderella tale turned into a soap opera. Or, paraphrasing Matti Kuusi's line of argumentation about the interrelation of poplore, folklore and history: knowledge about the Voitka saga stands for being aware of oneself, knowledge about its context, i.e. folklore, gives this self-awareness a historical perspective (Kuusi 1974: 23).

Like most outlaw legends, the saga of the Voitka brothers hardly changed anything in the society; nevertheless, it disclosed something about the society and its members.

The story of the Voitka brothers is more about the mentality of the Estonians than about the Voitkas. Looking at the Voitkas we see ourselves, our nature and aspirations. And what we see is not as nice as we wish it to be or as it might be. (Kolga 2000). 


\section{Comments}

* Forest brothers were Estonian men who in 1941 and mostly during 194453 fled to the woods to hide from Stalinist repressions and engaged in armed struggle against the Soviet occupational regime.

1. A romantic historical adventure about the Estonian's fight for freedom against German landlords and the Christian church (Tallinnfilm 1969).

2 The title of the article (Ai tsihk, ai tsahk, ai velled, me metsavennad oleme) was inspired by a well-known song from the repertoire of forest brothers.

3. See EFA I 45, 68/69. Interview with Marju Kõivupuu. Some local residents claim having seen Sabbe riding a bike to the river on a foggy morning, some believed that Sabbe escaped from his arrest alive.

4. Enn of Erastu is a well-known character, who cut off his thumb to escape the Russian army, in a play by Lydia Koidula (Säärane mulk ehk sada vakka tangusoola, 1872).

5. "Arst kirjutas noormeestele lampjalgu" ('Doctor diagnosed flatfeet on young men') (Saare, 1999), "Lampjalgade asemel arvutisõltuvus. Arvutiviirus muudab sõjaväe teatrilavaks" ('Computer addiction instead of flatfeet. Computer virus turns the army into a stage') (Vare 2000)

6. See the files of eccentrics and jokers in the Estonian Folklore Archives, see also Lõhmus 2000.

7. Jüri Rummo (Rummu Jüri), a farmhand at the Kehtna estate conducted more than forty thefts and robberies during 1876-1879, displaying remarkable skilfulness. He repeatedly escaped from almost impossible situations, once even descending from the Pikk Hermann tower in Tallinn on a rope. In 1880 the supreme court sentenced him to 15 years of servitude in a mine in Siberia (Ibius 1957).

8. The character emerged in literature very shortly after Jüri Rummo's robberies stopped. The character appeared as a simple robber in L. Koidula's „Kosjaviinad“ (written in 1880). In the poem „Röövli heategu“ by Jakob Tamm (written in 1893) he already appears as the guardian of peasants. He has also inspired a short story, a detective novel, a play and a musical (Vinkel 1966: 297). The latest version of the tale about a noble robber was an adventure film, where a popular Estonian actor Hannes Kaljujärv played the leading role.

9. The eight idol types proposed by Matti Kuusi (1974: 22) are ruler, messiah-martyr, killer, partner, fool or anti-idol, creator-pioneer, eccentricprankster-frawdster, artist. 
10. A serial killer of Russian origin who in the year 2002 killed 6 people in Estonia. According to Ustimenko himself, his actions were inspired by the positively depicted murderer in Russian cult movies Brat 1 and Brat 2.

11. „Media produces sports heroes to secure as large an audience as possible, to be as successful in economic activities as possible. A sports hero need media to gain popularity and as good income as possible." (see Song 2003: 3).

12. Kristiina and Katrin Shmigun, who are famous Estonian crosscountry skiers.

13. A fictional hero of the novel Tasuja by Eduard Bornhöhe (1880), who fought against German feudals in 1343

\section{References}

EFA - the manuscript files of the Estonian Folklore Archives

Bakhtin, Mihhail 1987. Valitud töid. [Selected works]. Tallinn: Eesti Raamat

Berendson, Risto 2000. Metsa vennad, meedia kangelased. [Brothers of the forest, heroes of the media] Eesti Päevaleht. Pluss. 29. Dec

Davidson H. R. E.(ed.) 1984. The Hero in Tradition and Folklore. The Folklore Society Mistletoe Series. Vol 19

EPL 2001 = Kas eliit käib vibe'il? [Does the social elite attend vibe rave parties?] Eesti Päevaleht, 2 January. http: //www.epl.ee/artikkel .php?ID=139009

Gašparíková, Viera and Putilov, Boris (eds) 2002. Герой или збойник? Образ разбойника в фольклоре Карпатсково региона. Heroes or Bandits: Outlaw Traditions in the Carpatian Region. Budapest: European Folklore Institute

Gräzin, Igor 2004. Essee. Õigus, Müüt ja õigusemüüt. . [Essay. Law, Myth and the Law of Myth] - Postimees, 7. March

Hagelberg, Tõnu, Oll, Sulev 1995. Ai tsihk, ai tsahk, ai velled! Maaleht, 5. January

Hiiob, Meelis 2000. Reklaamiklubi. Kummigrupi reklaam. .[Advertising club. Advertisement of Kummigrupp LLC] Eesti Ekspress, 30. March

Holt, J. C. 1984. Robin Hood. London: Thames and Hudson, pp. 7-13

Ibius, Otu 1957. Rummu Jürist kohtutoimikute valgusel. [On Jüri Rummo in the light of trial records] Sirp ja Vasar, 27. Dec

Illak, Kristiina 2004. Kuidas pääseda sõjaväest. [How to evade military service] Eesti Ekspress, 17. June

Jürgen, Madis 2000. Nagu laulupidu. Hõõgvein oli veel puudu. Vendade Voitkade kinnivõtmisest kujunes talve suurim meediasündmus. [Like a 
song festival. Only mulled wine was missing. The seizure of the Voitka brothers was the media highlight of this winter.] Eesti Ekspress, 2. March

Kivirähk, Andrus 2002. Kurjad külalised. [Evil guests] Eesti Päevaleht, 11. May

Kivirähk, Oskar 2000. Aasta inimeste nääripuu. [Christmas party of persons of the year] Eesti Päevaleht. Pluss, 29. Dec

Kohler, Vilja 2002. Vabad mehed kolivad Jänese matkarajale. [Free men move to the Jänese hiking trail] Tartu Postimees, 14. Nov

Kolga, Voldemar 2000. Arvamus. Voitkade lugu kui eestlase hingepeegel. [Opinion: The Voitka case as the mirror of an Estonian's soul] Eesti Päevaleht, 2. March

Koni, Juhan 2001. Voitkad ja valitsus. [The Voitkas and the government] Postimees, 19. February

Kuusi, Matti 1974. Poplore. Folklore tänään. Hämeenlinna: Suomalisen Kirjallisuuden Seura, pp. 11-23

Kärmas, Mihkel 1999. Vanamees ja lindpriid. [The old man and the outlaws] Eesti Ekspress, 10. June

Loorits, Oskar 1933. Koodi Jaan. Kuidas tekivad kangelasmüüdid? Meie, eestlased. [Jaan of Koodi. The emergence of heroic legends? We, the Estonians] Tartu: Ilmamaa 2000, pp. 108-121

Lõhmus, Alo 2000. Karand soldat, Jüri Rumm ja Voitkad. [Escaped soldier, Jüri Rummo and the Voitkas] - Postimees. Arter. 11. March

Maripuu, Aime 2000. Vennad Voitkad, olude ohvrid. [The Voitka brothers the victims of circumstances.] Postimees, 6. March

Mark, Margaret \& Pearson, Carol S. 2002. Kangelane ja lindprii. Kuidas luua arhetü̈̈pidele tuginevaid väljapaistvaid brände. Fontese Kirjastus. /2001. The Hero and the Outlaw. Building Extraordinary Brands Through the Power on Archetypes. McGraw-Hill/

Masing, Otto Wilhelm 1823. Kohtomõistmise otsused, mis Rias kinnitud. [Decisions of court trials recorded in Riga] Marahva Näddala-Leht, no. 27, July, pp 215

Muuli, Kalle 2001. Voitkad ajaviiteks. [The Voitkas for entertainment] Postimees, 19. February

Oinas, Felix 1966. Kalevipoeg, Rummu Jüri ja Stenka Razin. Mana, 314, pp 4-8

Paju, Imbi 2004. Film Voitkadest on suurepärane komöödia. [An excellent comedy - the Voitka documentary] Postimees, 1. Nov

Randla, Siim 2000. Müüt kohtukulli ees. [Myth tried in court] $S L$ Õhtuleht, 23. Nov

Rumm, Hannes 2000. Arvamus. Legendaarseim kurjategija..[Opinion. The most legendary of criminals] Eesti Päevaleht, 23. Nov

Russak, Ülo 2001. Ilveste impeerium. Vendade Voitkade lugu. [Empire of lynxes. The story of the Voitka brothers] Tallinn: Kirilille kirjastus 
Saare, Anu 1999. Arst kirjutas noormeestele lampjalgu. [Doctor diagnosed flatfeet on young men] Eesti Päevaleht, 8. Sept

Sikk, Rein 2000. Voitkad pääsesid põgenema. [The Voitkas in flight] Eesti Päevaleht, 1. April

Sildam, Toomas 1999. Vennad Voitkad naudivad kohalike elanike toetust. [The Voitka brothers enjoy the support of the locals] Postimees, 14. June

Sildam, Toomas 2004. Voitka filmi tegijad on vabad inimesed vabal maal.[Makers of the Voitka documentary are free men in a free country] Postimees, 1 . Nov

Song, Matis 2003. Spordikangelase kujutise konstrueerimine Eesti trükiajakirjanduses. Bakalaureusetöö. [Constructing the image of a sports hero in Estonian written press. BA thesis. Tartu: Department of Journalism and Communications, University of Tartu] Tartu: Ajakirjanduse ja kommunikatsiooni osakond

Soolep, Argo 2000. Voitkad muutis eriliseks mets. [Forest made the Voitka brothers special] SL Õhtuleht, 13. March

Sööt, Olav 2000. Voitkadele kergem karistus. [Milder punishment for the Voitkas] Postimees, 8. March

Tael, Inge 2000. Voitkad - inimesed meie hulgast. [The Voitkas - people among us] Postimees, 3. April

Tuvike, Väino 2000. Voitkadest ei saanud hunt-inimesi. [The Voitkas did not turn into wolf-men] Eesti Päevaleht, 2. Nov

Undusk, Jaan 2003. Retooriline sund Eesti nõukogude ajalookirjutuses. Võim ja kultuur. [Forced rhetorics in the Soviet Estonian treatments of history. Power and culture] Tartu: Eesti Kirjandusmuuseum. Eesti Kultuuriloo ja Folkloristika Keskus. pp 41-68

Vare, Priit 2000. Lampjalgade asemel arvutisõltuvus. Arvutiviirus muudab sõjaväe teatrilavaks..[Computer addiction instead of flatfeet. Computer virus turns army into a stage.] Eesti Ekspress, 9. March

Vaino, Margo 2003. Vennad Voitkad suvetuuril. [The Voitka brothers on summer tour] Maaleht, 24. July

Veidemann, Rein 2001. Pushkin ei saaks sellest loost ridagi. [Pushkin would not use a word from this story] Eesti Päevaleht. Arkaadia, 16. February

Vinkel, Aarne 1966. Eesti rahvaraamat. [Estonian Folk Book] Tallinn: Eesti Raamat

Virtapohja, Kalle 1998. Sankareiden salaisuudet. Journalistinen draama suomalaista urheilusankaria synnyttämässä. Saarijärvi:Atena Kustannus OY Jyväskylä

WF 1957 = Folklore in News. Western Folklore, pp. 212-213 